Journal of Jazz Studies vol. 10, no. 1, pp. 1-24 (Summer 2014)

\title{
Down to Business: Herman Lubinsky and the Postwar Music Industry
}

\author{
Robert Cherry and Jennifer Griffith
}

The historical record has emphasized how black performers were treated unfairly by the men who dominated the postwar music industry. Managers and venue operators, we are told, fell into dubious practices and the most contentious figures were the Jewish owners of independent record companies that sprang up in the 1940s. Accounts suggest that for several decades most artists relied on any owner who was willing to record them. In addition, the ubiquity of artists' drug addiction between the 1940s and 1970s has influenced studies of artist-owner relationships. It has prompted a deserved historical sympathy for the artists and, unfortunately, negative views of owners who were often perceived to take advantage of their vulnerability. Consequently, record company owners were in a position to exploit artists and only a few Jewish owners have escaped claims of unfair practices towards the black artists they recorded. ${ }^{1}$

In this article, we explore testimonies and written accounts of critics and biographers to show how contradictory and inconclusive evidence has led to simplistic notions of exploitive business practices. In particular, we explore the harsh negative assessment of Herman Lubinsky, owner of Savoy Records. Most importantly, we demonstrate that record owner practices were substantially affected by changes in conditions of the jazz market between 1930 and 1960. Judging the level of compensation for the artists has drawn rich discussion and advocacy: they certainly deserved more. But such judgments lie outside the scope of this article's inquiry, which concerns the reality of

\footnotetext{
${ }^{1}$ For critical assessments of Jewish involvement in postwar music industry, see Leroy Jones (Amiri Baraka), Blues People: Negro Music in White America (New York: William Morrow, 1969); Alain Locke, The Negro and His Music (New York: Arno Press, 1969); Jeffrey Melnick, A Right to Sing the Blues (Harvard University Press, 1999); Frank Kofsky, Black Music, White Business (New York: Pathfinder Press, 1998); Laurence Bergreen, Louis Armstrong: An Extravagant Life (Portland, OR: Broadway Books, 1997); Miles Davis, with Quincy Troupe, The Autobiography (New York: Simon \& Schuster, 1989); and Tommy James, Me, the Mob, and Music (New York: Scribner, 2010).
}

copyright by authors (c) Except where otherwise noted, this work is licensed under 
market forces in these decades. By attending to record industry economics, we might move toward a more nuanced view of the postwar era.

Jewish record owners' appreciation of the music, and their attitudes towards race politics, has heavily influenced assessments of their treatment of black artists. ${ }^{2}$ At the top of what amounts to a morality scale are the dogooders: Jewish owners who were both genuine jazz fans and deeply committed to the mid-century struggle for racial equality. Milt Gabler (Commodore), Norman Granz (Verve) and Alfred Lion (Blue Note) have been regularly commended for their impeccable musical taste, pro-equality racial views, and avoidance of unfair business practices. Just below this tier are those Jewish owners who have been subject to some criticism for allegedly underpaying black artists. ${ }^{3}$ Jerry Wexler (Atlantic) ${ }^{4}$ and Bob Weinstock (Prestige) are included in this group. However, because of their genuine appreciation for the music, and respect for the black culture from which it arose, these men have largely escaped harsh criticisms.

A tier seemingly more prone to exploitation comprises Jewish owners, most prominently Leonard Chess (Chess) and Syd Nathan (King), whoalthough they may not have started out as fans of the music-could spot talent, and entered through their employment in other areas of the entertainment field. Their entrepreneurial instincts led to some success producing and selling records. Though initially these entrepreneurs focused singularly on profitability, some eventually gained an appreciation for the music and the artists they recorded. These men also played a positive role in furthering good relations between black and white-Nathan, through his efforts to end Jim Crow hiring practices, and Chess through the blackoriented radio station he owned. ${ }^{5}$

Nathan drew his labor force from the multi-ethnic, multi-racial Cincinnati community. Included on his application for work was: "Do you object to working with a person of a different religion or race," Zella Nathan

\footnotetext{
${ }^{2}$ John Broven has provided testimony depicting Jerry Wexler and the Ahmet Ertegun (at Atlantic Records) as the elite, or "royalty," of the business, but we confine our analysis to Jewish owners in this article.

${ }^{3}$ Underpaying refers to the amount companies subtracted for studio expense charges, not to the terms of royalties artists earned, which were determined by the American Federation of Musicians union scale.

${ }^{4}$ Wexler was brought in by Ahmet Ertegun at Atlantic Records.

${ }^{5}$ For Chess, see Nadine Cohodas, Spinning Blues into Gold: The Chess Brothers and the Legendary Chess Records (New York: St. Martin's Press, 2000); for Nathan, see Steve Tracy, Going to Cincinnati: A History of the Blues in the Queen City (Chicago: University of Illinois Press, 1993). For Nathan's generosity towards Otis Redding's nascent production group, see Scott Freeman, Otis! The Otis Redding Story (New York: St Martin's Press, 2001), 93.
} 
recalled. "If you put yes, you were not hired." ${ }^{\circ}$ In 1949, the Cincinnati Post reported on how Nathan's business policies undermined Jim Crow segregation:

Two year ago they told ... the King Record Co. ... that it couldn't be done. "Cincinnati is a border town," said the skeptics. "You can't get Negroes and white people to work together. It's too close to the south ..."

The skeptics were wrong ... The musical director, assistant office manager, foreman of the mill room, set up man on the production line, assistant promotion director, legal secretary, a dozen stenographers and 20 percent of the factory workers are Negroes ... "We pay for ability," says [operations manager] Mr. Siegel, "and ability has no color, no race, and no religion. Our hiring policy and our promotion system are based only on the question of the individual's capacity to fill a given job."

At the bottom of the scale are record company owners who never gained an overt appreciation for the music or artists they recorded, held no appreciation for the culture from which the music arose, and seemingly paid no attention to advancing the rights of African Americans. The most-often identified member of this group is Herman Lubinsky, owner of Savoy Records. Music writer Frank Kofsky claims that Lubinsky had a "scarcely disguised distain for black art," due to his "unwillingness to develop any understanding - appreciation, of course, was entirely out of the question-of the art that brought him such lucrative returns."

Lubinsky's son, Herman ("Dink") Lubinsky Jr., admitted that his father had little interest in the artists outside of business dealings. When asked if Herman, Sr. socialized or took individual artists aside, he recalled, "He might have [taken an artist aside]. He might have done that. But did he have them over to his house for dinner? No. Did he go out and socialize? No. Nothing like that."

Not surprisingly, critics contend that Lubinsky's insensitivity towards black music and the black experience was mirrored in his business practices. Atlantic recording executive Joel Dorn called Lubinsky "a hemorrhoid of a human ... whom even the worst record business golems of the era shunned." 10

' Julia Goldman, “The Other 'King' of Rock 'n' Roll,” The Jewish Week (Aug 15, 2003) 21-22.

${ }^{7}$ Steve Tracy, Going to Cincinnati: A History of the Blues in the Queen City (University of Illinois Press, 1993) 120-121.

${ }^{8}$ Frank Kofsky, Black Music, White Business ([n. c.]: Pathfinder, 1998), 42-43.

${ }^{9}$ H. Lubinsky Jr., interview, January 31, 2012.

${ }^{10}$ Shaun Dale, "It's Not a Normal Life: Cosmik Interview with Joel Dorn," accessed 11/12/10, http://www.cosmik.com/aa-april01/joel_dorn.html. 
Billboard executive Paul Ackerman characterized Lubinsky's operations as "slave barracks." ${ }^{11}$ As a result, Lubinsky has become such a pariah that "when the New Jersey Performing Arts Center was about to mount a program on Savoy Records," related Newark historian Clement Price, "we decided that it might be too controversial given the then coded notion that the company may have unfairly treated its black artists and we canned the event." 12

We contend that whatever Lubinsky's personal shortcomings, the evidence of his having treated black artists worse-in terms of business dealings - than other independents remains unconvincing. Randall Sandke agrees that Lubinsky "earned a dismal reputation by paying musicians as little as possible." ${ }^{13}$ Sandke, however, does not believe that Lubinsky exhibited different behavior among Savoy's "interracial array of artists." ${ }^{14}$ Whatever his shortcomings, Lubinsky fulfilled the necessary role that music-industry middlemen played: "the necessary link between black artists and white audiences ... opening up unprecedented opportunities for African American artists." ${ }^{15}$ Tiny Prince, who covered the night-club scene for the Herald News in the 1940s, observed:

There is no doubt everybody hated Herman Lubinsky ... At the same time, some of those people-many of Newark's top singers and musicians-would never have been exposed to records if he didn't do what he did. Except for Lubinsky, all the hot little numbers, like Buddy Johnson's "Cherry" would have been lost. The man may have been hated, but he saved a lot of our history-for us and for future generations." 16

We situate Lubinsky, more generally, in the highly competitive world of the independent record owners in the postwar era. The behavior of Jewish record owners during this period, we argue, reflected more the changing economics of the industry than their personal attitudes. Jazz as a commercial enterprise had its ups and downs across the mid-century, but in times of decline, most record companies became desperate to survive and were forced to make difficult business decisions. To highlight these economic concerns, we

\footnotetext{
${ }^{11}$ Quoted in David Ritz, Faith in Time: The Life of Jimmy Scott (New York: Da Capo, 2002), 92.

${ }^{12}$ Clement Price, personal correspondence, January 20, 2012.

${ }^{13}$ Randall Sandke, Where the Dark and Light Folks Meet (Lanham, MD: Scarecrow Press, 2010), 172.

${ }^{14} \mathrm{Ibid}, 172$.

${ }^{15}$ Ibid., 197.

${ }_{16}$ Barbara Kukla, Swing City: Newark Nightlife, 1925-50 (Philadelphia, PN: Temple University Press, 1991), 158.
} 
will show how differences in business practices of such exemplary figures as Norman Granz and Milt Gabler, compared to those of George Wein and Bob Weinstock, were the result of the changing financial viability of jazz recordings and concerts.

\section{SAVOY RECORDS}

Herman Lubinsky's first love was electronics and, as owner of United Radio based in Newark, NJ, began selling records out of his radio parts store. This led to the establishment of Savoy Records in 1942. He recorded some of the first bebop jazz sessions, capturing the early work of Charlie Parker, Miles Davis, and Dexter Gordon. From the start he recorded a blues component that included artists such as Varetta Dillard, Big Maybelle, and Nappy Brown. ${ }^{17}$

While Savoy had produced gospel records from the beginning-including a Clara Ward bestseller in 1949-Lubinsky only began to concentrate on gospel when he refused to give payola (the practice of pay-for-play in radio stations), when it became widespread in the late 1950s. "Lubinsky didn't appreciate that type of operation, and we didn't have it in the gospel fieldand still don't," explained Fred Mendelsohn. "There are not that many companies and not that many releases. Jockeys are happy to get new gospel releases." ${ }^{18}$ In the 1960s, Lubinsky and his company men helped church singers, like the Reverend James Cleveland and Dorothy Norwood, to become household names in black neighborhoods nationwide. When Lubinsky died in 1974, still working out of Savoy's Newark office, Clive Davis at Arista Records acquired the label's catalogue. ${ }^{19}$

Stories of Lubinsky's tight-fistedness are legendary. Lubinsky's eldest daughter, Lois Grossberg has stated,

He had a reputation as an ogre in the business ... You have no idea of the cheapness. He paid his bills, but he was always arguing with the

\footnotetext{
${ }^{17}$ According to Bob Porter, a broadcaster and record producer who worked at Savoy during the Arista ownership beginning in 1975, Lubinsky also tried western music, Yiddish, sweet bands and novelty recordings in the early years, but gradually moved away from these in favor of black music styles. Bob Porter, personal communication, May 13, 2012.

${ }^{18}$ Arnold Shaw, Honkers and Shouters: The Golden Years Of Rhythm And Blues (New York: Crowell-Collier Press, 1978), 356.

${ }^{19}$ Barbara Kukla, Swing City: Newark Nightlife, 1925-50 (Philadelphia: Temple University Press, 1991), 153. Bob Porter reports that Screen Gems, the music publisher which partnered with Arista, was folded into the deal when Arista bought Savoy (B. Porter, personal communication, April 11, 2011).
} 
repairmen. He always thought he was getting gypped. Other than a Fleetwood Cadillac and a boat at the Shore, he didn't have any simple pleasures. He never enjoyed his money. ${ }^{20}$

Relying on the testimony of the musicians, Barbara Kukla has highlighted Lubinsky's mistreatment of a local Newark (NJ) group, The Dictators. Lubinsky's first recording venture was to release four of their tunes, in 1942, without giving them any money, even for the recording sessions. Though they admitted that they eventually earned "a few dollars," the experience more than soured the group on Lubinsky. Without knowing what the initial agreement was, or if Lubinsky made money on the recording, it becomes difficult to evaluate this evidence. When interviewed decades later, Al Henderson, the group's lead singer, claimed, “There ain't nobody who has ever had a kind word to say about him. The S.O.B. was the worst thief in the world. He made millions on us [black musicians] and he wouldn't pay you nothin." ${ }^{21}$ But the Dictators' lack of subsequent recordings through other companies also suggests that Lubinsky was hardly responsible for their relatively small success. ${ }^{22}$

Lubinsky had little understanding of the music Savoy produced but he employed a series of highly talented Jewish A\&R men (artists and repertoire): Teddy Reig, Fred Mendelsohn, Ralph Bass, and Lee Magid. He was astute to rely on them to recruit new artists, and for their judgments concerning recording decisions. These A\&R men believed that Savoy was no different than its competitors in its financial treatment of black artists. Fred Mendelsohn described the financial constraints that Savoy and others worked under. His testimony points to conditions under which royalty payments were later a possible source of confusion for artists.

Herman was a very tough, hard individual, difficult to work for and often an intolerable man. But he was honest. None of the musicians really were robbed. They all signed contracts and got five percent royalties. The fact was the money for the session had to be recouped before they got royalties, not just at Savoy, at every company. ${ }^{23}$

\footnotetext{
${ }^{20}$ Quoted in Kukla, 154. Arnold Shaw (351) noted that Lubinsky had a bachelor's apartment in New York City where he was "acting the man-about-town."

${ }^{21}$ Kukla, 155.

${ }^{22}$ Kukla (155-56) cited the claims of Picadilly Pipers who alleged that after their hit "Don't Stop Now" sold 80,000 copies, Lubinsky only gave them $\$ 75$ instead of the $\$ 8,000$ the group felt they deserved. Even if the sales figure is accurate, at 2 cents per record, the gross would have been $\$ 1,600$ from which recording expenses had to be subtracted.

${ }^{23}$ Kukla, 157.
} 
Here, Mendelsohn described the standard contracts that artists signed. Contracts gave artists a fixed percentage -3 to 5 percent-of the record sales as royalties, minus the cost of producing the record and any advances given. ${ }^{24}$ While certainly the owners could "cook the books" by overstating recording costs, the main problem less successful artists faced was a lack of sufficient record sales, especially in the 1950s as jazz record buying waned. In addition, most contracts were for the exclusive right to record. Thus, if another label wanted to record an artist under contract, it would have to negotiate with the label that held the exclusive right.

Summing up the financial risk, Herman Lubinsky, Jr. portrays his father's position (or the position of any record company owner) in light of his experience of artists' inflation of their own success:

When you hire a studio, and you hire a band, and an arranger, and studio time, and all of this stuff ... And you bring a guy in, and you give him some money for coming in. You pay the musicians and background singers, and you put the record out, and you have them printed and stamped ... and the record doesn't sell-you're out that. There's no remuneration for that. Then a guy maybe sells 10,000 records, and then tells you he sold 100,000 or a million-they all do that. ${ }^{25}$

Lubinsky, Jr. notes that,

My old man's gotten a lot of bad rap as not being good to artists or for being tough ... A lot of artists will say the old white independents screwed them. But my father never took a penny of royalties from those people, and the woman who worked for him for 45 years taking care of that, Helen Gottesman, she wouldn't take a nickel. ${ }^{26}$

Another A\&R man, Lee Magid, who left Savoy because of the minimal salary he received, suggested that in the highly competitive music world of the 1950s, where survival was uncertain, the independents had to fight for every dollar they could. He argued,

Lubinsky is one of those old, hardcore guys, like Syd Nathan, of another era. But he keeps a tight rein. And that's the way it's supposed to be. I

\footnotetext{
${ }^{24}$ Our efforts to obtain information about Savoy's contracts and financials—of the decades we discuss-were unsuccessful. Should we have gotten the flights and accomodations, Dan Marx, in charge of Savoy's historical records, was available on too limited a basis to accompany us to a remote warehouse in Georgia where they are stored.

${ }^{25}$ Herman Lubinsky Jr., interview, January, 2012.

${ }^{26}$ Bill Carpenter, Mavis Staples, and Edwin Hawkins, Uncloudy Days: the Gospel Music Encyclopedia (Milwaukee, WI: Backbeat Books, 2005), 259.
} 
don't care. Maybe he ain't right with this and maybe he ain't right with that, but then who is? Unless you're dealing with your top companies. ${ }^{27}$

Arnold Shaw had business dealings with Lubinsky when he joined Edward B. Marks Music Corporation. Assessing Lubinsky, Shaw concluded,

Having fought his way to eminence in a very tough field, Lubinsky was never an easy spender. But record producer John Hammond remembers him as a man who was helpful to many jazz musicians; apparently, Herman guarded his generosity. He was a hearty, energetic and dedicated man, and I liked him. ${ }^{28}$

These more favorable assessments, of course, obscure the potential thievery by omission that looms over such "deals." Artists who had seen only unfair contracts were hardly in a position to recognize a fair deal or to know how to make a better deal. But this occurred throughout the record business. Kukla sums up,

From the artists' perspective, Lubinsky was a wily, unethical shark out for bucks, a man who could locate a vulnerable point, then go for the jugular. But times were hard, opportunities limited, and money tight, so they tended to set aside their fears and suspicions, succumbing to what often amounted to their only chance to record their music. ${ }^{29}$

Sadly, the artist had little choice in the early recording environment except to see it as a means toward gaining exposure, not as a money stream from the music recorded. Herman Lubinsky Jr. points out that,

The artist would get what was coming to him with the royalties. The purpose of a record for an artist wasn't the royalties, like today where they sell millions and millions. The purpose was to get you known and get you booked, your manager gets you in clubs and gets you a tour ... I mean, only if you were a Sinatra or a Crosby, you might make a lot of money. ${ }^{30}$

\footnotetext{
${ }^{27}$ Shaw, 363.

${ }^{28}$ Shaw, 351.

${ }^{29}$ Kukla, 155-156.

${ }^{30}$ H. Lubinsky Jr., interview, January, 2012. Dink's testimony points to other branches of exploitation. In exploring the origins of claims of artist exploitation, and clarifying Lubinsky's role, we might examine divisions outside company owners' domain that confuse and complicate matters of artists receiving their financial due. During the postwar period, artists made most of their money on live appearances. Recordings were used to create publicity, which helped artists obtain more concert dates and higher pay for their performances. Hence, live performances increasingly became opportunities for exploitation-by venue operators,
} 
According to one account, Savoy supposedly took advantage of Charlie Parker, not paying him for songs recorded in 1945, including "Ko-Ko." Subsequent behavior by Parker, however, supports the idea that he had a square deal from Lubinsky. (At this stage in his career he might more than likely have recorded for cash to support his drug habit.) Even at the height of his popularity in the late 1940s, there seemed to have been no hard feelings between Parker and Lubinsky. In December 1947, Reig approached Parker to do another session on Savoy. According to Miles Davis, "Billy Shaw, who had a lot of influence over Bird and was, I think, a co-manager, told Bird that he had to stop recording for small labels like Dial and stick with a big label, like Savoy." ${ }^{1}$ Although not a definitive indication that Parker was always treated fairly by Savoy, Davis's story calls into question claims that Lubinsky was among the worst exploiters.

\section{SAVOY AND LITTLE ESTHER}

Esther Mae Jones's story further illustrates the complexity and competitiveness of the independent record company environment in postwar years. In 1949, Lubinsky visited Los Angeles where he immediately signed the thirteen-year old Esther Mae Jones, known as "Little Esther," who had stopped the show cold at an amateur night performance. She was a singer in Johnny Otis's band, and her first Savoy recording, under the guidance of Otis and Ralph Bass, produced the classic tune, "Double Crossin' Blues." The side was an immediate hit and made her a star. By the end of 1950, Little Esther had six record releases, many with Otis's band, all good sellers, one true classic, and a host of awards and in-person appearances that made her a nationally known performer. ${ }^{32}$

Controversy arose after the new year began. On January 5, 1951, the Superior Court of California appointed Esther's mother as her legal guardian

booking agents, and managers. Jimmy Scott's case serves as an example of how artistic careers were vulnerable to unfair practices particularly by managers (see Shaw, 358). See also David Ritz, 58-59, for claims of exploitation against Gladys Hampton (manager of Lionel Hampton's band), and 71-72 for Magid and Wexler's assessments of Teddy Reig in relationship to promoter Jimmy Evans, with personal stories from Chuck Berry and Jimmy Scott.

${ }^{31}$ Miles Davis with Quincy Troupe, Miles: The Autobiography (New York: Simon \& Schuster, 1989), 106. By "big," Shaw means those labels with good distribution and an advertising relationship with Billboard, Cash Box, or other industry trade publications that published charts of song popularity.

${ }^{32}$ J. C. Marion, "The Story of Little Esther," accessed 10/12/10, http://home.earthlink.net/ jaymar41/Lesther.html. 
and upheld a new contract for her to record for King Records. In May, Esther Mae Jones sued Savoy Records for back earnings. In November, Jones decided to leave King Records, signing on with Mercury Records. King then sued and the courts ruled that her contract with Mercury Records was invalid. And in May 1952, Little Esther settled her suit (out of court) against Savoy Records on the issue of back owed royalties.

By 1954, Little Esther's stardom had begun to fade as her recordings ceased to be bestsellers, but her career was resurrected after she began recording with Savoy in 1956. The first new Savoy recording, paired "You Can Bet Your Life" with "T'ain't Whatcha Say It's Whatcha Do," and while not a national hit, it sold especially well in the Midwest where it reached No. 3 in Cincinnati. ${ }^{33}$ Little Esther intermittently recorded for Savoy for another few years. After she left Savoy, her records drew weak sales, She resumed her professional career in the mid-1960s, including a hit single, "Release Me" and continued to perform until her death in 1984.

Little Esther's career struggles highlight the difficulty in judging fairness between independent record companies and their artists. Certainly, Lubinsky's initial risks and efforts propelled Little Esther quickly into stardom, but her ability to move among competing record companies also demonstrates how record companies had limited ability to control (or exploit) successful artists.

\section{SAVOY AND LITTLE JIMMY SCOTT}

A more publicized case is Lubinsky's questionable treatment of the jazz singer, Little Jimmy Scott. In his biography of Doc Pomus, Alex Halberstadt emphasizes their business relationship. Pomus and Scott met right after the war and socialized regularly. "Doc knew more about black music-loved it more passionately - than anyone in the world," Jimmy Scott said. "And Docfrom the moment I met him until the day he died-provided all the encouragement I needed." ${ }^{34}$

Their relationship picked up twenty years later when Pomus began searching for Scott. When Pomus contacted him, Scott was playing in a "dingy club" in Newark. According to Halberstadt,

Jimmy had lived the life of a musical Job since they'd parted. In 1962 it looked like his days of obscurity were over when Ray Charles, a devoted

\footnotetext{
${ }^{33}$ Ibid., and "Best Sellers," in Rhythm and Blues (June 23, 1956), 60. [The claim, as reported in these sources, that "You Can Bet Your Life" had any action on the R\&B charts remains controversial;.]

${ }^{34}$ Ritz, 51-52.
} 
fan [and as ABC-Paramount artist, had] recorded him with an orchestra for his Tangerine label. The sublime [Falling in Love is Wonderful] was certain to finally get Jimmy noticed, but it never made it to the stores [because] Lubinsky claimed he had Scott under contract for years to come and threatened to sue, and Charles pulled the record. Scott came out of retirement in 1969, and again in 1972 when Joel Dorn coaxed him into a studio to record a pair of albums for Atlantic. ${ }^{35}$

But, as Halberstadt reports, Lubinsky squashed these records, too, and Doc's favorite singer returned to sorting mail at the Sheraton. Pomus tried to help, but Scott was too beaten down to show up for studio work. In the end, Scott regained his career, Halberstadt writes, when, during the funeral service for Pomus in 1991, Sire Records co-founder heard him singing a Gershwin ballad. Shortly after, Scott was signed to a five-record deal with Sire. ${ }^{36}$

Lubinsky's treatment of artists may have been no different than any other independent record company owner. His actions toward Scott likely reflect the money lost during Scott's years at Savoy; Scott cut sixty sides at Savoy, none were successful, and he was still under contract in the 1960s. Ritz stated that "When producer Freddy Mendelsohn gave him more commercial material, the results were banal and sometimes painful." 37 And Scott complained, "Lubinsky wanted me to make more rock-sounding records but I just wasn't willing." 38

Explaining why Lubinsky fought the Tangerine release, his son Herman Jr. offered, "He felt like he put good money into Jimmy with little results. When Jimmy suddenly turned up with an album distributed by ABC, Dad was incensed. If Jimmy had initially come to him and asked for permission ... I have a feeling that my father would have agreed." ${ }^{39}$

Finally, Lubinsky's business relationship with Scott conformed to typical industry practices. During the postwar years, it was customary for an interested producer to contact a prospective artist's record company, in order to obtain a financial arrangement that allowed a contracted artist to perform for another

\footnotetext{
${ }^{35}$ Halberstadt, 212.

${ }^{36}$ Halberstadt, 225.

${ }^{37}$ Ritz, 95. "The DeLuxe Jimmy Scott sides were produced by Fred Mendelsohn who worked for DeLuxe (1956-59) before returning to Savoy. There was no loan out involved." (B. Porter, personal communication, May 13, 2012.)

38 Ritz, 119. Scott also seemed to become increasingly irresponsible. When Lubinsky attempted one last time to make a successful record, Scott missed numerous rehearsals. And when the 1959 album, "Fabulous Songs of Jimmy Scott" flopped, Lubinsky tried to promote a Scott single by arranging for him to appear on the NYC TV show, Teen Bandstand. Scott arrived unprepared, forgetting the words to the song, forcing him to ad lib with disastrous results (Ritz, 117-118).

${ }^{39}$ Ritz, 135.
} 
company. Indeed, Lubinsky had done as much with many other artists, and even lent Scott out to King Records in the 1950s.

According to British deejay and jazz historian Spencer Leigh, Ray Charles seemed unwilling to enter into any agreement with Savoy. Music reviewer Don Williamson claims that "Rather than contest [the Savoy contract] or come to an agreement, Ray Charles withdrew the album. Undoubtedly, part of Charles's calculation was the fact that the album had flopped in its three weeks of distribution. There were no major reviews, no profiles of the singer, no media interest whatsoever." 40 Instead, according to Leigh, "Charles erased Jimmy's vocals and asked the organist Wild Bill Davis

to play over the tracks. Hence, Wild Bill's album, 'Wonderful World of Love."'41

Leigh also points out that Atlantic, though "flush with money," chose not to fight Lubinsky, then decided to make a second album, "even though there was no hope of a release." ${ }^{2}$ Scott's own testimony also found fault with Atlantic: "Atlantic didn't care about the record in the first place. The idea of a legal expense-even a small one to call Lubinsky's bluff-was all they needed to back out." 43 However, the details of Jimmy Scott's contract, which he fails to mention, would likely have kept either Ray Charles or Atlantic from contesting the situation. In light of the testimony and standard business practices presented here, the opinion that Lubinsky exploited Scott becomes problematic. Scott never became a profitable recording artist and Lubinsky had every right to expect some compensation for lending him to another label.

\section{COMPETITIVE CAPITALISM}

To better understand Lubinsky's treatment of artists we might explore how competition shaped his behavior and that of other record company owners. In the postwar period, over a thousand new start-ups competed for talent to record under their wing. ${ }^{44}$ Facing such competition, individual owners had to keep costs as low as possible in order to survive. All three of Savoy's A\&R men at one time or another owned independent record companies that had failed. Unless one had a star performer under contract-such as Savoy had with

\footnotetext{
${ }^{40}$ Ritz, 135.

${ }^{41}$ Spencer Leigh, "Someone to Watch over Me: An appreciation of Jimmy Scott," accessed 10/12/10, http://www.spencerleigh.demon.co.uk/Feature_Scott.html.

${ }^{42}$ Leigh.

${ }^{43}$ Ritz, 158.

${ }^{44}$ Rick Kennedy and Randy McNutt, Little Labels - Big Sound (Bloomington, IN: Indiana University Press, 1999).
} 
James Cleveland in the 1960s-profitability in the recording business was not guaranteed. While ownership rights had always been profitable, their value increased dramatically in the late 1960s, when the use of music in television and films became much more lucrative. Until then, both owners and artists at all but the major recording companies rarely achieved financial security.

While much has been written about the few that were successful, typically these companies failed. When Jerry Wexler reminisced about Atlantic's competitors in the early 1950s, he listed some of these labels and the grizzled infighters who owned them: Exclusive (Leon and Otis Rene), Modern (the Biharis), Imperial (Lew Chudd) Specialty (Art Rupe), Old Town (Hymie Weiss), Herald/Ember (Al Silver), Chess (Leonard Chess), and other such memorable logos. Wexler concluded, "I am reminded of the tribes of the Sinai desert-the Hittites, the Moabites, the Midianites, the Amorites. Gone, perished, vanished from the face of the earth. Only one survived-the Hebrews." ${ }^{45}$

The cost of survival? Struggling company owners had to balance their books and used revenues gained from their successful artists to pay for their failures. The recording sessions, advances, and unsold records that accumulated expenses with no subsequent revenue were paid for by "underpaying" those who were successful. In this way, owners could make their record companies viable.

Independent companies had another formidable obstacle: the difficulty of directly marketing their records. In the first postwar decade, independents relied on record distributors who often undermined profitability. Bob Krasnow, whose own dealings with distributors forced him to sell Blue Thumb, an independent label he founded. He described them thus: "They weren't what I would call criminals, but let's put it this way-I wouldn't like either of [my two daughters] to ever marry an independent distributor." ${ }^{46}$

Similarly, Lee Magid recounted why he shutdown his fledgling record company, "I started Dawn Records and recorded a chick, Helen Thompson, who came from Georgia. She had a Ruth Brown quality and sold pretty well. But everybody was giving me funny counts, and I didn't see a fast enough return for me." ${ }^{47}$ Such distributor behavior caused Fred Mendelsohn's company's demise. He recounted,

\footnotetext{
${ }^{45}$ Jerry Wexler and David Ritz, Rhythm and the Blues (New York: Alfred A. Knopf, 1993), 183.

${ }^{46}$ Quoted in Dorothy Wade and Justine Picardie, Music Man: Abmet Ertegun, Atlantic Records and the Triumph of Rock ' $n$ ' Roll (New York: W. W. Norton, 1990), 67.

${ }^{47}$ Shaw, 360.
} 
At one point [Regal] put out a kiddie line of seven-inch records but at 78 speed. We sold them by the hundreds of thousands, but somehow we were losing money. Then the government came in and wanted to tax us on the jackets plus the records. Jules Braun, one of the partners, was a lawyer and he decided that we were going to fight-and that led to the dissolution of Regal Records. ${ }^{48}$

The free movement of unsigned artists among record labels was not uncommon in the postwar environment as few independents offered contracts. While there certainly could have been cases where onerous contracts locked artists unfairly to uncaring record owners, Little Esther's movement among record producers would have been more common than the plight of Jimmy Scott. According to Teddy Reig,

Nobody really wanted [contracts]. The artist wanted to stay free in case he got hot and got an offer from a major label. The owners, on the other hand, didn't want to make a commitment either. If you signed an artist to a year's contract, you would have to guarantee him twelve or sixteen sides. If you tried to get out after four, the federation could prevent you from doing any other dates until you lived up to your end of the bargain. Take a guy like John Lee Hooker. This guy was on 50,000 labels! Anyone with \$100 in his pocket was cutting four sides with him! ${ }^{49}$

Contracts were given out for exclusivity only, according to Bob Porter, who worked at Savoy in the 1970s. "Everything else was a one-shot—often without artist royalties. Sheet music sales were smaller and smaller with each passing year. [The] money was in mechanical and performance royalties." ${ }^{50}$ Companies had always tried to hold onto the publishing rights of the songs they recorded for sheet music sales and covers. Publishing rights also accrued money from the music licensing rights agencies, such as ASCAP and BMI, who monitored radio (and TV) play. These often account for the biggest payments a composer or publisher might receive.

In the 1950s, short-changing occurred when artists were unable to keep their publishing rights, but almost all owners had little idea they were acquiring assets that would become so valuable in the future. Indeed, Herb Abramson sold his one-quarter interest in Atlantic Records, including publishing rights, for only $\$ 300,000$ in December, 1958 , when the company's

\footnotetext{
${ }^{48}$ Shaw, 355.

${ }^{49}$ Teddy Reig, Reminiscing in Tempo: The Life and Times of a Jazz Hustler, with Edward Berger (Lanham, MD: Scarecrow Press, 1995), 35.

${ }^{50}$ B. Porter, personal communication, May 13, 2012.
} 
record sales were booming. And yet a little over a decade later, Wexler and Ertegun sold Atlantic for $\$ 17.5$ million.

Within a few years, the Chess estate received $\$ 6.5$ million for Chess Records, the Nathan estate less than $\$ 5$ million for King Records, and the Lubinsky estate less than $\$ 2$ million for Savoy. Indeed even these sums might have been less than their true market value. When Morris Levy was forced to sell the publishing rights to his Roulette label in 1986, he received $\$ 55$ million, a sum that dwarfed prices received by independents who sold their labels in the late 1960s and early 1970s.

\section{DECLINING JAZZ SALES}

The ebb and flow of jazz popularity most heavily influenced the viability of record companies, yet assessments have seemingly glossed over its effects on business practices. Norman Granz and Milt Gabler entered the jazz field during the war years when jazz's soaring popularity enabled them to gain footholds insulated from the competitive pressures postwar independents faced. Both gained positions that enabled them to bypass discovering new talent or investing in unknowns. Gabler began at Decca in 1942,51 producing leading jazz figures, while Granz managed, organized, promoted, and recorded concerts for various labels including his own. Moreover, by the time jazz interest waned, the most creative portion of Gabler's career at Decca had ended, while Granz had terminated his U.S. concert series, shifting to the still lucrative overseas market. His stable of jazz legends allowed him to issue a limited number of successful jazz recordings in the 1950s.

By contrast, during 1930s and the 1950s, small companies were forced to make compromises in order to survive. When record sales fell in the early 1930s to a scant 6 percent of their 1927 sales, many of the earliest independents failed; and the larger companies curtailed or eliminated their "race" catalogues. ${ }^{52}$ At the same time, middle-class black Americans were responding favorably to the smoothly harmonized arrangements of big bands like Jimmy Dorsey's. ${ }^{53}$

While record sales eventually did increase, Duke Ellington's manager, Irving Mills, chose to accommodate to this environment. Mills was not

${ }^{51}$ Gabler's own label, Commodore Records's lifespan overlaps his work with Decca; the former label was hardly active by the mid-1940s.

${ }^{52}$ H. F. Mooney, "Popular Music since the 1920s," in William Hammel, ed. The Popular Arts in America (Harcourt Brace Jovanivich, 1972), 253. Sales were bad in 1931-32, but improved thereafter.

${ }^{53}$ Mooney, 254. 
insensitive to the tension between the innovative and commercial jazz. While the big bands emphasized commercial fare, Mills formed Ellington's "band within a band," as with the recording of "Mood Indigo," which displays the talents of individual musicians.

To further this innovation, in 1936 Mills started the Variety record label where many musicians from different bands came together in small groups to record in an informal or "natural" manner. Variety provided a glimpse into one of the most inspiring periods of American music and into the bristling jazz scene. The small group records were done to promote Ellington the composer, and the musicians in his band who got an important extra payday and broader exposure. Unfortunately, by 1938, mounting financial losses forced Mills to disband Variety, although other labels picked up some of the artists and recording contracts. ${ }^{54}$

Mills had fought segregation. He was one of the first managers to record black and white musicians together, combining twelve white musicians with the Duke Ellington Orchestra. When Victor Records first hedged on releasing the record, Mills threatened to take his artists off their roster and won out. ${ }^{55} \mathrm{In}$ addition, he made every effort to have the Ellington Band perform at previously all-white venues. He also booked the band as the first African American musical attraction to appear at the Avalon club in St. Louis (1931), the Academy Awards (1934), and the Orpheum in Memphis (1937). ${ }^{56}$ As Mills' client Cab Calloway stated, "Mills broke down so many darned barriers for Negro musicians you couldn't count them." 57

Some, like the music historian Harvey Cohen, looked positively at this response because it "created an audience considerably less constricted in taste and tolerance, than the 'experts' realized." ${ }^{8}$ However, many jazz aficionados did not. Despite his efforts to break segregationist barriers, and despite his Variety recordings, Mills has been harshly attacked as responsible for Ellington's compromise and departure from some critics' core beliefs. First among these critics was John Hammond, who in 1935 wrote that Ellington's "music is losing its distinctive flavor it once had, both because of the fact that

\footnotetext{
${ }^{54}$ Quoted in Jim Prohaska, "Irving Mills: The Master and Variety Record Labels," accessed July 28, 2012, http://iajrc.org/docs/irving_mills_variety.pdf.

${ }^{55}$ Bob Mills, "Irving Mills," accessed July 28, 2012, http://www.redhotjazz.com/irvingmills.html.

${ }^{56}$ Harvey Cohen, "The Marketing of Duke Ellington: Setting the Strategy for an African American Maestro," Journal of African American History 89, no. 4 (Aug 2004), 308.

${ }^{57}$ Quoted in Sandke, 184.

${ }^{58}$ Cohen, 303, and fn 39.
} 
he had added slick, un-Negroid musicians to his band and because he himself is aping Tin Pan Alley composers for commercial reasons." ${ }^{59}$

Similar problems were faced by jazz record owners in the 1950s, when jazz sales were in decline. Like Gabler, Bob Weinstock developed a passion for jazz at an early age and he, too, became a collector of older jazz records. Weinstock became a familiar figure at New York City jazz clubs, befriending many of the artists. In 1949, he launched the Prestige label but, unlike Gabler, had no stable of jazz legends or concert recordings. He scrambled for talent and made recordings of many lesser figures or complete unknowns in the highly competitive postwar environment.

Without access to the older generation of jazz legends, Weinstock sought out younger innovative artists, including Miles Davis, John Coltrane, Sonny Rollins, and Thelonious Monk. While we now recognize their profound talents, most were unable to attract a large record-buying audience in the dwindling market. As a result, Weinstock, like his competitors, had to cut corners on expenses. For example, he would not pay for rehearsals and instead charged against royalties the extended recording sessions he used in order to find his coveted "authentic" sound. ${ }^{60}$

For Lubinsky, cost-cutting business practices led to a disgruntled Jimmy Scott; at Prestige it led an exasperated saxophonist, Jackie McLean, to complain, "If you can imagine being under the Nazi regime and not knowing it then you've got an idea of what it's like to be with that company." ${ }^{\prime 1}$

McLean related how Prestige took advantage of his financial situation.

They give you a little bit of front money, and then they tell you about the royalties you are going to get after the record is released. I did a million dates for them, and all it amounted to is that I paid for the whole thing: engineers, the notes on the back of the album, the color photographs, the whole thing, out of my money. I still get statements saying that I owe

${ }^{59}$ Quoted in Sandke, 19; see also John Hammond, "The Tragedy of Duke Ellington, the 'Black prince of jazz," Down Beat (Nov 1935), 1, 6. Hammond and Ellington were known to have disliked each other, as Hammond's testimony reflects. Ellington responded with "Situation between the Critics and Musicians Is Laughable," in Down Beat, May 1939. As Mark Tucker has written: "Ellington ... attacks critics who judge musicians by a uniform standard rather than taking into account individual goals. He points out the shortcomings of half a dozen writers, reserving his harshest words for John Hammond, whose article 'The Tragedy of Duke Ellington' had appeared in Down Beat a few years earlier. To air such negative opinions publicly was rare for Ellington." In Mark Tucker's The Duke Ellington Reader (New York: Oxford University Press, 1995), 132.

${ }^{60}$ In the late 1950s and 60s, Prestige became very successful concentrating on recording organ-tenor sax duos.

${ }^{61}$ A. B. Spellman, Four Lives in the Bebop Business (New York: Random House, Inc., 1966). 
that company ridiculous sums like $\$ 50,000$; I'm exaggerating, but it's not much less ridiculous than that. ${ }^{62}$

Jerry Wexler later expressed his frustration about the kind of criticism McLean leveled on Prestige. McLean's anger demonstrated his misinformation about how the business worked. As Wexler explained, session expenses-for publicity, musicians, the studio, etc.-were deducted from what royalties the artist might earn from sales. Major companies gave 5\% per record sold where independents gave 3\%, after all expenses were deducted. Wexler recounted,

Leonard [Chess] thinks we're crazy to pay our artists as high as 5 percent, as high as the majors, and believes firmly in a cutoff point, regardless of sales. I argue that a straight account makes good business, but Leonard counters that there are virtually no defections from Chess. "They're just happy to be making records," he says. "The records get them club dates." ${ }^{\prime 3}$

Wexler lamented that although Atlantic paid major company rates, if an artist failed to sell a lot of records, the recording sessions ate up the little that came back in royalties. Thus, given his limited sales, even if McLean had contracted at $5 \%$, he would still not have made any money.

The late 1950s produced many disappointed artists, some of them embittered-not understanding the economic realities of the down years of jazz - when their work failed to sell. Unfortunately, their personal accounts have been used uncritically to generalize about the record company's behavior. Music critic Frank Kofsky used McLean's story to buttress his claim that it "was notorious in jazz circles that Weinstock habitually took advantage of musicians who were desperate for money-often because of an addiction to heroin-by signing them to contracts requiring them to record a huge number of selections in exchange for a minute advance against future royalty payments. ${ }^{64}$ As history showed, some artists with a drug addiction faced insurmountable challenges surviving in such an environment, but Kofsky ignores that declining jazz sales gave Weinstock (like Lubinsky) no choice but to cut labor costs if he wanted Prestige to survive.

Another late arrival on the scene was the promoter George Wein. Although he held similar leftwing, anti-racist sensibilities as Norman Granz, the condition of jazz sales during their careers was completely different. As a

\footnotetext{
${ }^{62}$ Kofsky, 52-53.

${ }^{63}$ Wexler, Rhythm and Blues, 101.

${ }^{64}$ Kofsky, 52.
} 
jazz pianist Wein had the same appreciation of the music, if not more than Granz, but, less fortunately, he entered the concert business in 1954. His singular achievement was in finding sponsorship for jazz and selling it to the broader public. As a result of declining sales in jazz, profitability of his concerts was not guaranteed; he had to look at the commercial viability of his endeavors. This meant he included acts considered "impure," or blues bands. ${ }^{65}$

For this, Wein was roundly criticized by many, including Nat Hentoff, who in 1959 wrote, "The Newport Jazz Festival has nothing to do with the future of jazz. It is a last if large gasp of the more expendable show-biz, conman, fast-talking-agent, tent shows, musician-come-in-the-back-door past of jazz." ${ }^{66}$ Hentoff and others ignored that, only as a result of the increased attendance these non-jazz artists brought, Wein was able to present the "pure" artists the critics desired.

A second complaint asserted that, to maintain financial viability, Wein underpaid performers. A famous example concerns Miles Davis, who pulled out of the 1972 Carnegie Hall Newport Jazz Festival, contending that he should be paid more and referring to the festival as "George Wein's plantation." ${ }^{67}$ Thus, regardless of his commitment and beliefs, Wein could never be considered a promoter equal to Granz. "Despite the years of work devoted to jazz and the jazz musician, I remain a target," Wein lamented. "The Man. The Producer. The 'Enemy.' So it's tantalizingly easy to take shots at me." ${ }^{\prime 28}$

Finally, the history of Atlantic Records also illustrates how the shift in music popularity in the 1950s impacted recording decisions. Reflecting on his and Ahmet Ertegun approach at Atlantic Records, Wexler said,

[We] could have developed a label along the lines of Blue Note, Prestige, Vanguard or Folkways, fastidious documentarians of core American music. Bobby Weinstock, Alfred Lion, Moe Asch, Orrin Keepnews, Manny Solomon and the other keepers of the flame were doing God's work. Ahmet and I, however, didn't feature ourselves as divinely elected. We weren't looking for canonization; we lusted for hits. ${ }^{69}$

Although Ertegun and Wexler were as much jazz aficionados as these producers, they moved rapidly into pop, soul and nascent rock and roll,

\footnotetext{
${ }^{65}$ George Wein, with Nate Chinen, Myself Among Others: A Life in Music (New York: Da Capo Press, 2003), 330-331.

${ }^{66}$ Wein, 491.

${ }^{67}$ Quoted in Wein, 466.

${ }^{68}$ Wein, 418.

${ }^{69}$ Wexler and Ritz, Rhythm and the Blues, 91.
} 
making their company quite profitable. We have seen that in the 1970s, it allowed them to record Jimmy Scott without any serious intentions of marketing his output. In the 1950's, this profitability also allowed Atlantic to maintain its ties to the blues and jazz world without having to compromise music integrity. The label produced a series of non-commercial records that united contemporary musicians with older musical styles. For a 1956 Joe Turner recording Boss of the Blues, Wexler assembled a small ensemble of veteran jazz musicians that included legendary boogie-woogie pianist Pete Johnson. Likewise, on an album titled Blues from the Gutter, Champion Jack Dupree performed his drug-themed compositions along with interpretations of the earliest blues standards, backed by a superbly sensitive band.

Indeed, its pop music success enabled Atlantic to form a jazz division, headed by Ahmet's brother Nesuhi. ${ }^{70}$ Nesuhi soon assembled dozens of recordings by avant-garde musicians such as Ornette Coleman, John Coltrane and Charles Mingus. Though most of these recordings were not profitable, they provided a link to the past that both Wexler and Ahmet cherished. ${ }^{71}$

\section{CONCLUSIONS}

The evidence presented here suggests that the animus towards Lubinsky has not originated from specific business practices, but rather stems from a difference of values: Artists, understandably, valued their art, and they (and historians who have captured their stories) have been hostile to Lubinsky in partial assessments of artist-owner relationships; they fail to take into account that he viewed his record company solely as a commercial enterprise. Particularly when owners had to fight for survival, profitability led to music compromises that incensed artists and critics alike. Indeed, based largely on these perceptions, the music historian Alain Locke lamented in the 1930s that owing to Jewish involvement, black music "is tarnished with commercialism and the dust of the market-place." ${ }^{72}$ Wein nicely summarizes the inherent tension between the middleman and the artist:

The declining sales of jazz records are reflected in diminishing ticket sales, and you can't have a festival without people. Success for my work lies in compromise between commercial and artistic pursuits. I keep

\footnotetext{
70 See Nesubi Ertegun heading under "Atlantic Records," accessed August 16, 2012, http://en.wikipedia.org/wiki/Atlantic_Records.

71 Alex Halberstadt, “Jerry Wexler," Salon (Sept 5, 2000), accessed 11/11/2011, http://dir.salon.com/people/bc/2000/09/05/wexler/index.html.

${ }^{72}$ Locke, The Negro and His Music, 4.
} 
sponsors not only because my shows draw people, but also because I do so while maintaining a certain artistic credibility. In this way, I'm no different now than I was in Newport in 1954.

I don't equate success with profit-yet without profit there is no success. That profit may come from a subsidy, or a sponsor, it may come entirely from ticket sales. Whatever the case, a venture has to be paid for in one way or another. Artistry alone cannot create a success-although it is the critical ingredient. I've had a plethora of losing artistic successes, and they leave a bitter taste in your mouth. In one way, this represents a complete change of perspective since the days of [my Boston nightclub] Storyville, when I was happy to be able to present Duke Ellington even to a half-empty house. ${ }^{73}$

So, the ebb and flow of profitability explains the different perceptions of Savoy's business practices between its jazz and gospel days. In particular, Savoy only became consistently profitable in the 1960s when it concentrated on gospel music. Considerably fewer complaints have surfaced from the gospel singers Savoy recorded, and even some praise. ${ }^{74}$ Indeed, it was mainly the gospel recording rights Savoy owned that accounted for its $\$ 1.8$ million selling price after Lubinsky's death in 1974.

In the political and cultural changes that developed in the 1980s and 90s, record owners provided an easy target, and their perceived transgressions became the primary focus of historians, scholars, and artists alike. They easily fit into views that Jewish middlemen invariably exploited the black community and thus justified black anger. ${ }^{75}$ The agency of these owners has been so inflated as to eclipse economic factors or the influences of distributors, bandleaders, and managers. The vilification of Herman Lubinsky is understandable and predictable. He was a profit-driven, by-and-large indifferent, white entrepreneur in a business where black artists could be treated badly. While others in the record industry may have used the same business practices, they were often judged less harshly because of their sympathies for the music performed.

Ideological and aesthetic predispositions have necessarily led those in the position to write about music, or to write historical accounts, to emphasize the narrative of victim versus villain: powerless artists (Scott or McLean) versus

\footnotetext{
${ }^{73}$ Wein, 518, 519-520.

${ }^{74}$ See Charles Sanders, "James Cleveland: King of Gospel," Ebony XXIV (Nov 1968), 26, 39; and Tony Heilbut, The Gospel Sound (New York: Simon \& Schuster, 1971).

${ }^{75}$ For a discussion of Jewish middleman theories, see Robert Cherry, "Middleman Minority Theories: Their Implications for Black-Jewish Relations, Journal of Ethnic Studies 17 (Winter 1990): 117-138.
} 
all-powerful owners (Lubinsky or Weinstock). By foregrounding economic factors of the era, and how these influenced business behavior, we might arrive at more nuanced conclusions about the ways in which artists and owners survived in the competitive mid-century jazz market.

\section{WORKS CITED}

Berry, Chuck. Chuck Berry: The Autobiography. New York: Harmony Books, 1987.

Broven, John. Record Makers and Breakers: Voices of the Independent Rock 'n' Roll Pioneers. Champaign, IL: University of Illinois, 2009.

Carpenter, Bill, and Mavis Staples, et al. Uncloudy Days: the Gospel Music Encyclopedia. Milwaukee, WI: Backbeat Books, 2005.

Cohen, Harvey. "The Marketing of Duke Ellington: Setting the Strategy for an African American Maestro." Journal of African American History 89, no. 4 (Aug 2004), 291-310.

Dale, Shaun. "It's Not a Normal Life: Cosmik Interview with Joel Dorn." Accessed 11/12/10. http://www.cosmik.com/aa-april01/joel_dorn.html.

Davis, Miles, and Quincy Troupe. Miles: The Autobiography. New York: Simon \& Schuster, 1989.

Deffaa, Chip. Blue Rhythms: Six Lives in Rhythm and Blues. Champaign, IL: University of Illinois Press, 1996.

Goldman, Judith. "The Other 'King' of Rock 'n' Roll.” The Jerwish Week (Aug 15, 2003) 21-22.

Halberstadt, Alex. Lonely Avenue: The Unlikely Life and Times of Doc Pomus. New York: Da Capo Press, 2007.

Heilbut, Tony. The Gospel Sound. New York: Simon and Schuster, 1971.

Kennedy, Rick, and Randy McNutt. Little Labels - Big Sound: Small Record Companies and the Rise of American Music. Bloomington, IN: Indiana University Press, 1999.

Kofsky, Frank. Black Music, White Business: Illuminating the History and Political Economy of Jazz. New York: Pathfinder Press, 1998.

Kukla, Barbara. Swing City: Newark Nightlife, 1925-50. Philadelphia, PA: Temple University Press, 1991. 
Leigh, Spencer. "Someone to Watch over Me: An appreciation of Jimmy Scott" (2004). Accessed 10/10/10. http://www.spencerleigh.demon.co.uk/Feature_Scott.htm.

Lowrance, Heath. "How the Great Depression Gave America the Blues." History Magazine (August, 2008). Accessed 6/5/11. http://sites.google.com/site/thegreatdepressionblues/.

Marion, J. C. "The Story of Little Esther." Accessed 10/12/10. http://home.earthlink.net/ jaymar41/Lesther.html.

Mooney, H. F. "Popular Music since the 1920s" in The Popular Arts in America. Edited by William M. Hammel. New York: Harcourt Brace Jovanovich, 1972.

Reig, Teddy. Reminiscing in Tempo: The Life and Times of a Jazz Hustler. With Edward Berger. Lanham, MD: Scarecrow Press, 1995.

Ritz, David. Faith in Time: The Life of Jimmy Scott. New York: Da Capo Press, 2002.

Sanders, Charles. "James Cleveland: King of Gospel." Ebony XXIV (November 1968), 26, 39.

Sandke, Randall. Where the Dark and Light Folks Meet. Lanham, MD: Scarecrow Press, 2010.

Shaw, Arnold. Honkers and Shouters: The Golden Years Of Rhythm And Blues. New York: Crowell-Collier Press, 1978.

Spellman, A. B. Four Lives in the Bebop Business. New York: Hal Leonard Corporation, 1994. Originally published in 1966.

Tracy, Steve. Going to Cincinnati: A History of the Blues in the Queen City. Champaign, IL: University of Illinois Press, 1993.

Wade, Dorothy, and Justine Picardie. Music Man: Abmet Ertegun, Atlantic Records and the Triumph of Rock ' $n$ ' Roll. New York: W. W. Norton, 1990.

Wexler, Jerry, and David Ritz. Rhythm and the Blues: A Life in American Music. New York: Alfred A. Knopf, 1993. 


\section{About the Contributors}

Robert Cherry is Stern Professor at Brooklyn College and the Graduate Center of City University of New York. He has written extensively on economic discrimination and public policy, most recently Moving Working Families Forward (NYU Press, 2012). His interest in Jewish middlemen in the jazz industry is part of a book project, The Pleasure Principle: How Jewish Values Shaped Twentieth Century Popular Culture.

JENNIFER GRIFFITH moves between jazz scholarship and her creative efforts as a composer. She has written on composer/bandleader/bassist Charles Mingus's reanimations of early jazz, and his response to the legacies of vaudeville and minstrelsy (Jazz Perspectives, 2010). Her article on Mingus's Jazz Workshop, and his leadership in performances that invoke the trance rituals of black Pentecostal spiritual communion, is forthcoming (Black Music Research Journal, 2015). She studied composition with Donald Wheelock, Thea Musgrave, David Del Tredici and Tania León.

The Journal of Jazz Studies (JJS) is published by the Institute of Jazz Studies at the Newark campus of Rutgers, The State University of New Jersey. JJS is hosted online by the Rutgers University Libraries at http://jjs.libraries.rutgers.edu. 